\title{
Stress and Subjective Health of Teachers ${ }^{1}$
}

\section{Karel Paulík}

\begin{abstract}
This article focuses on the psychological contexts of subjective health among teachers in relation to their perception and evaluation of work-related stress in the teaching profession. The research was carried out on a sample of teachers from Czech and Slovak primary schools $(. \mathrm{N}=2501)$ during 2009-2011 using the subjective perception methodology.

The aim of the article is to consider the connections between subjective evaluation of stress and health among teachers, and between subjective and objective indicators of individuals' state of health.

The results indicate that there exist negative and statistically significant ( $1 \%$ level) but weak (lower than -0.2) correlations between perceptions of work-related stress and subjective health. This suggests that this relationship is probably mediated by other variables; in our research these were personality factors from the Big Five model (neuroticism and extraversion) and the variables optimism, hardiness and sense of coherence.

The connection between subjective and objective health is illustrated by correlation coefficients whose values were statistically significant (1\%) yet likewise weak (around $0.2)$; this suggests that other influences are also likely to be involved.
\end{abstract}

This study was carried out as part of the Czech Science Foundation grant project no. 406/09/0726 "Coping with Load by Men and Women". 
Key words: Subjective health, Big Five, stress, cognitive appraisal, optimism, sense of coherence

\section{Introduction}

This article focuses on several psychological issues related to the subjective evaluation of the load experienced in connection with the teaching profession and teachers' subjective evaluation of their health. The discussion is based on a research carried out in 2009-2011 involving a total of 2501 teachers from the upper year-groups ('Level 2') of primary schools in the Czech Republic and Slovakia, using subjective perception methods to generate data for analysis.

The aims of the article are to consider the following questions:

1. What is the relationship between subjective evaluation of load and teachers' health?

2. What role is played by selected personality characteristics in the subjective evaluation of health?

3. What are the possible relationships between subjective health and objective indicators of an individual's health?

The teaching profession is generally considered to be a highly demanding one. Authors have frequently discussed the occurrence of high-load situations in the profession (e.g. Průcha, 2002, Oravcová, 2010, Popelková, Šišková, Zat'ková, 2010, Kohoutek, Řehulka, 2011 , etc.). However, it is also quite frequently stated (e. g. B. Lazarová et al., 2011) that teachers' workload often reaches levels that can be classified as stress (viewing stress as a special case of load which is highly non-optimal in relation to the possibilities and needs of teachers - see e. g. Hladký et al., 1993; Paulík et al., 2009). From the viewpoint of health, acute and long-term intense stress can be viewed as more or less of a risk factor, although the relationship between stress and health is not a simple and unambiguous one in view of the range of other factors which impinge upon this relationship (cf. Kebza, 2005; Gillnerová et al., 2011). Many authors agree (e. g. Šolcová, Kebza, 2006) that health is a multidimensional phenomenon, and that its individual dimensions are interlinked with each other to varying degrees. From the psychological viewpoint, the most interesting dimension is the subjective experience of health. This is referred to as 'subjective health', though a range of other terms are used - e. g. subjective health status, self-reported health, self-rated health, perceived health, etc.

The evaluation and perception of one's own health plays a major role in human life. The importance of this role is reflected in the World Health Organization's definition of health, which emphasizes the subjective dimension as part of the construct of 'well-being' (cf. e. g. Gillnerová et al., 2011) - which is linked to the maintenance of all life functions, social roles and the adaptability of the organism. Subjective health 
is one of the important indicators of an individual's state of health, and can be used for various purposes (e.g. for research, the selection and evaluation of therapeutic approaches, etc.). The use of subjective health in this way brings several advantages; it can be determined simply and relatively easily, and it has strong predictive force e.g. for mortality or the application of treatment methods (cf. Šolcová, Kebza, 2006). An individual's subjective report on his/her own health is generally more extensive and wider-ranging than an objective medical diagnosis, thus enabling researchers to gain more data for various types of analysis.

This article focuses on subjective health of teachers in connection with their perception of the load to which they are subjected in their profession and in their life outside work. Research by several authors has indicated that teachers have a tendency to give relatively negative evaluations of their own state of health. For example, Vašina, Valošková (1998), based on a comparison of a large sample of teachers $(M=2240)$ with a representative sample of economically active inhabitants of one region in the Czech Republic ( $\mathrm{N}=998)$, state that teachers more frequently (to statistically significant levels) complain of health problems and give an overall lower evaluation of their own health than the economically active population as a whole. Female respondents listed more health complaints and evaluated their health more negatively than male respondents. Similar results were also given in my previous research (e.g. Paulík, 2001).

A further question to be examined here concerns the factors which influence the relationship between subjective load and subjective health. I focus particularly on the personality characteristics captured in the Big Five (five-factor) model, optimism and sense of coherence (SOC). In this connection I am primarily interested in the phenomenon of salutogenesis, which according to Antonovsky (1993) helps to support and develop health, restoring health after illness, reinforcing health and preventing health problems. Antonovsky views health as a lifelong process, and attempts to define the more general factors which help individuals achieve health. Many different personality factors and environmental factors can have a protective effect. Among the personality factors of salutogenesis Antonovsky identifies the sense of coherence (SOC), which is characterized by a stable and dynamic global tendency to see one's life space as essentially ordered, predictable and manageable. This vision of the human world thus offers hope that the course of events has a certain meaningful order, which can be expected or purposely influenced if necessary. Antonovsky sees SOC as a source of health. Individuals who score highly for SOC also display a high degree of flexibility when using potential sources of adaptation to load. 


\section{Research}

The research presented in this article was carried out between 2009 and 2011 at Czech and Slovak primary schools (for more details see Paulík, 2010a; 2010c; 2011; Paulík et al., 2009). The composition of the samples of respondents - consisting of teachers from the upper year groups ('Level 2') of primary schools - is shown in Table 1.

Table 1: Composition of respondent samples - teachers from Level 2 of primary schools

\begin{tabular}{|c|c|c|c|c|}
\hline \multirow{2}{*}{ Set } & $\begin{array}{c}2009 \\
\text { Czech teachers }\end{array}$ & $\begin{array}{c}2009 \\
\text { Slovak teachers }\end{array}$ & $\begin{array}{c}2010 \\
\text { Slovak teachers }\end{array}$ & $\begin{array}{c}2011 \\
\text { Czech teachers }\end{array}$ \\
& Total 463 & Total 509 & Total 557 & $\mathrm{N}=972$ \\
& Male 88 & Male 81 & Male 87 & Male 169 \\
& Female 375 & Female 428 & Female 470 & Female 803 \\
\hline
\end{tabular}

\section{Methods}

The research focused on determining the subjective evaluation of health by teachers using a 5-point scale ranging from the lowest (1) to the highest (5) level of health. A similar scale was also used to determine the subjective degree of work-related and non-work-related load ( 1 = minimum, 5 = maximum load). The objective indicator of health selected was the number of days on which respondents were absent from work due to illness in the past year. Data on absence from work is generally considered to be an indirect indicator of work-related load (Vašina, Valošková, 1998). In order to determine the factors from the Big Five personality model, the NEO FFI inventory was used (Urbánek, Hebíčková, 2001); optimism was evaluated using the LOPS (Levi OptimismPessimism Scale - see Sarmány, 1992), consisting of 16 items measured on 6-point scales. SOC was measured using the SOC29 inventory (Antonovsky, 1993), translated into Czech by J. Křivohlavý. This inventory consists of 29 items with responses given on 7-point scales.

\section{Results}

\section{Relation between teachers' subjective evaluations of health and load/mediators}

An overview of the evaluation of work-related and non-work-related load, subjective health and days absent from work due to illness is given in Table 2. 
Table 2: Teachers' evaluation of load and state of health

\begin{tabular}{|l|c|c|c|c|c|c|c|c|}
\hline & \multicolumn{2}{|c|}{2009} & \multicolumn{2}{c|}{2009} & \multicolumn{2}{c|}{$\begin{array}{c}2010 \\
\text { Slovak teachers }\end{array}$} & \multicolumn{2}{c|}{$\begin{array}{c}2011 \\
\text { Czech teachers }\end{array}$} \\
\hline & Mean & \multicolumn{1}{|c|}{ SD } & Mean & \multicolumn{1}{c|}{ SD } & Mean & SD & Mean & SD \\
\hline Work-related load & 3.20 & 0.812 & 2.88 & 0.872 & 2.89 & 0.880 & 3.05 & 0.859 \\
\hline $\begin{array}{l}\text { Non-work-related } \\
\text { load }\end{array}$ & 2.72 & 0.729 & 2.64 & 0.796 & 2.64 & 0.788 & 2.68 & 0.766 \\
\hline Subjective health & 3.79 & 0.792 & 3.81 & 0.803 & 3.89 & 0.841 & 3.85 & 0.826 \\
\hline $\begin{array}{l}\text { Absence due } \\
\text { to illness }\end{array}$ & 6.93 & 6.810 & 7.05 & 6.875 & 6.13 & 6.924 & 6.50 & 7.168 \\
\hline SOC & 133.66 & 17.375 & 135.71 & 20.170 & - & - & 136.62 & 18.413 \\
\hline Optimism & 64.53 & 9.871 & 65.37 & 10.363 & - & - & - & - \\
\hline
\end{tabular}

The mean evaluation of work-related and non-work-related load in the Czech and Slovak respondents ranged from 2.88 to 3.20 (work-related load) and 2.64 to 2.72 (nonwork-related load); this corresponds with medium levels of load.

In all cases, non-work-related load was statistically significantly lower than workrelated load. The proportion of teachers who perceived their work as bringing heavy or extreme load (e.g. as being stressful) ranged from $22.7 \%$ to $38.6 \%$ in the sets included in Table 1. In the sets of Czech $(\mathrm{N}=972)$ and Slovak $(\mathrm{N}=557)$ teachers, the correlation coefficients for the relation between subjective health and perception of work-related load were low. Their values $(-0.14$ and -0.11$)$ were statistically significant to $1 \%$ significance level. The correlations between perceived work-related stress and days absent from work due to illness were also low $(-0.18$ and -0.11$)$, though they were also statistically significant to $1 \%$ significance level. The respondents' subjective evaluation of their own health ranged from 3.79 to 3.85 , corresponding with the evaluation "fairly healthy".

For a more detailed analysis of the relationship between perception of load and subjective health, the method proposed by Baron and Kenny (1986) was used, applying the regression analysis. In order to estimate the mediating effect of the investigated variables, three regression equations were used. Baron and Kenny state that the following conditions must be met in order to prove a mediation effect:

1. In the first regression equation $\times 2=a 1+b x 1$

- in the regressive relationship between the independent variable (predictor) $x 1$ (in this case, work-related load) and the mediator $x 2$ (one of the examined variables from the Big Five model, optimism, SOC), the predictor must influence the mediator (the coefficient of simple linear regression between the independent variable and the mediator b must be statistically significant).

2. In the second regression equation $y=a 2+b^{\prime} \times 1$

- in the regressive relationship between the predictor $x 1$ (work-related load) and the predicted y (subjective health), the predictor must influence the predicted (the coefficient of simple linear regression b' must be statistically significant). 
3. In the third regression equation $y=a 3+b 1 \times 1+b 2 \times 2$

- in the multiple regression of the independent variable (work-related load) and the dependent variable (subjective health), the mediator $x 2$ (a variable from the selected personality characteristics) must influence the predicted y (the dependent variable subjective health). The coefficient of multiple regression b2 must be statistically significant. The influence of the predictor upon the predicted must be greater in multiple regression than in simple regression (the multiple regression coefficient $b 1$ must be higher than the simple regression coefficient $b^{\prime}$ ). An ideal 'pure mediation' would require the multiple regression equation to show no effect of the independent variable upon the dependent variable (b1 to be statistically insignificant). The calculated values of the regression coefficients for the verification of the mediator hypothesis are shown in Table 3.

Table 3: Regression coefficients

\begin{tabular}{|l|c|c|c|c|}
\hline & $\mathbf{b}$ & $\mathbf{b}^{\prime}$ & $\mathbf{b} 1$ & $\mathbf{b} 2$ \\
\hline Extroversion & $.142^{++}$ & $.196^{++}$ & $-.135^{++}$ & .178 \\
\hline Neuroticism & $.548^{++}$ & $.196^{++}$ & $-.140^{++}$ & -.192 \\
\hline SOC & $-.481^{++}$ & $.196^{++}$ & $-.139^{++}$ & .216 \\
\hline Optimism & $.477^{++}$ & $.196^{++}$ & $-.132^{++}$ & .185 \\
\hline
\end{tabular}

Table 3 shows $b$ as the coefficient of simple linear regression between the independent variable and the mediator; $b$ ' as the coefficient of simple linear regression between the independent variable (work-related load) and the dependent variable (subjective health); b1 as the coefficient of multiple regression between the predictor (work-related load) and the predicted (subjective health); b2 as the coefficient of multiple regression between the variables playing the role of mediator (personality variables) and the predicted.

The results presented in Table 3 (data for other variables are given in Paulík et al., 2009) show that the coefficients $b, b^{\prime}$ and $b 2$ are statistically significant and that the value of $b 1$ is higher than that of $b^{\prime}$ for the Big Five factors extroversion and neuroticism and for optimism and SOC. This means that these variables act as mediators for the relationship between work-related load and subjective health according to the criteria of Baron and Kenny (1986).

Focusing more closely on the role of SOC as a variable which - according to its originator A. Antonovsky (1993) - has a major effect on human health (Paulík, 2011), the correlation with the monitored variables is given in Table 4. 
Table 4: Correlations of SOC

\begin{tabular}{|l|c|}
\hline Variable & Spearman's correlation coefficient \\
\hline Subjective health & 2.13 \\
\hline Objective health (days absent) & -.035 \\
\hline Work-related load & -0.093 \\
\hline Non-work-related load & -0.216 \\
\hline
\end{tabular}

In this research, SOC correlated with subjective health, work-related and non-work related load. In view of the size of the sample ( 972 Czech primary school teachers), these correlations are significant to $1 \%$. No statistically significant correlation was found between the objective health indicator (absence due to illness) and SOC; the value (-.035) was not statistically significant even to $5 \%$.

In order to examine other connections between SOC and health indicators, the respondents were divided (cf. Paulík, 2011) into individuals with high and low scores for SOC. The criterion for the allocation to these groups was the median value. The first group (high SOC) consisted of individuals whose mean score was equal to or higher than the median; the second group (low SOC) consisted of those whose mean score was lower than the median. The mean values of subjective health (3.70 for the low SOC group and 4.00 for high SOC) differed for both groups with statistical significance to $1 \%$ (t-test 6.41). As for the objective indicator of health - the number of days absent from work due to illness - this showed no statistically significant variance either for the low-SOC group (mean 6.37, standard deviation 15.68) or for the high-SOC group (mean 6.63 , standard deviation 18.59).

\section{Links between subjective health and objective health indicators}

The links between subjective health and the selected indicator of objective health are given in Table 5 for the Czech and Slovak primary school teachers.

Table 5: Indicators of subjective and objective health

\begin{tabular}{|l|c|c|c|c|}
\hline Study & \multicolumn{2}{|c|}{2010} & \multicolumn{2}{c|}{2011} \\
\hline Set & \multicolumn{2}{|c|}{$\mathrm{N}=557$} & \multicolumn{2}{c|}{$\mathrm{N}=972$} \\
\hline & Subj. health & Days absent & 3.85 & Days absent \\
\hline Mean & 3.89 & 6.13 & 0.83 & 17.168 \\
\hline Standard deviation & 0.84 & 16.92 & \multicolumn{2}{c|}{-0.17} \\
\hline Correlation & \multicolumn{2}{|c|}{-0.18} & \multicolumn{2}{c|}{$1 \%$} \\
\hline Significance & \multicolumn{2}{|c|}{$1 \%$} & \multicolumn{2}{c|}{} \\
\hline
\end{tabular}


The mean subjective evaluation of health for both groups of the respondents corresponds with the verbal evaluation "fairly healthy".

The connection between subjective health (expressed in response to a direct question and evaluated on a 5-point scale) and objective health (in this case, expressed as the number of days absent from work due to illness) is illustrated by the correlation coefficients; the values of these coefficients were 0.18 for the Slovak teachers $(N=557)$, which is statistically significant to $1 \%$, and -0.17 for the Czech teachers $(\mathrm{N}=972)$, which is also statistically significant to $1 \%$.

\section{Discussion and conclusions}

The results presented in this paper support the assumption that the teaching profession is evaluated as a relatively highly demanding one in terms of teachers' own subjective evaluation of work-related load. For the sets of respondents, the evaluation of workrelated load was statistically significantly higher than their evaluation of non-workrelated load, and the proportion of stressed teachers ranged approximately between $20 \%$ and $40 \%$ - which corresponds with other results obtained from Czech and Slovak primary school teachers (e. g. Paulík, 1999, Štětovská, Skalníková, 2004 etc.).

The consequences of teachers' stress also include negative effects on health, although the influence of stress on health cannot be considered to be unambiguous and direct. This study focused on subjective health as evaluated by teachers, and an objective indicator of health, i.e. the number of days absent from work due to illness. Based on a calculation of correlations, it was found that the connections between the perception of work-related stress and subjective health are not random, and that the subjective evaluation of the respondents' own health has a tendency to worsen with growing load. Nevertheless, given that the statistically significant negative correlation coefficients were low (no higher than 0.14 ), the relationship between perceived load and teachers' health is probably also influenced by other factors. A regression analysis based on Baron and Kenny (1986) suggests that the influential factors include several components of the Big Five personality model (neuroticism and extroversion), as well as variables which appear to be connected with health and the ability to cope with load (see e. g. Paulík, 2010b) - SOC and optimism. These factors probably play the role of mediators, which impinge upon the relationship between work-related load and subjective health in such a way as to change the nature of this relationship, also helping to explain the consequences and mechanisms of this effect. In this research, the variable SOC appears to be a salutogenetic factor due to (a) its significant positive correlation with subjective health and its negative correlation with work-related and non-work-related load, and (b) the significant difference in subjective health between 
individuals with high SOC and those with low SOC (those with higher SOC evaluated their health more positively than those with low SOC).

With regard to the relationship between subjective and objective health, the correlations proved to be statistically significant for the research sample. Nevertheless, the correlations were low, which suggests that subjective and objective health are phenomena which display not only several similarities, but also certain differences. This is also shown in other studies (cf. Šolcová, Kebza, 2006).

\section{References}

Anatonovsky, A. (1993) The Structure and Properties of the Sense of Coherence Scale. Social Science and Medicine, 36, pp. 725-733.

Baron, R. M. \& KENNY, D. A. (1986). The Moderator-mediator Variable Distinction in Social Psychological Research. Journal of Personality and Social Psychology, 51, 6, 1173-1182.

Hladký, A. et al. (1993). Zdravotní aspekty zátěže a stresu. Praha: UK.

Kebza, V. (2005). Psychosociální determinanty zdraví. Praha: Academia.

Kohoutek, R. \& Rehulka, E. (2011) Stressors in the Work of Primary and Secondary Teachers in the Czech Republic. In Řehulka, E. (Ed.) School and Health for the $21^{\text {st }}$ Century. Health Education: Initiatives for Educational Areas. Brno: MSD, pp.109-22.

Lazarová, B. (Ed.) (2011). Pozdní sběr. O práci zkušených učitelů. Brno: Paido.

Gillernová, I., Kebza, V., Rymeš, M. at all. (2011). Psychologické aspekty změn v české společnosti. Člověk na prelomu tisíciletí. Praha: Grada.

Oravcová, J. Náročné interakčné situácie v škole a ich zvládanie. In Valihorivá, M. \& Kaliská, L. (Eds.), (2010). Zdravá škola. Banská Bystrica: UMB, pp. 284-298.

Paulík, K. Subjektivní hodnocení vlastního zdraví učitelů. In Řehulka E., Řehulková, O. (Eds). Učitelé a zdraví 3. Brno: Psychologický ústav AV ČR, nakl. Pavel Křepela, pp. 41-50.

Paulík, K. (2010a). Perception of Workload by Men and Women Teachers and Self-assesed Health Status. In Řehulka, E. (Ed.). School and Health 21. Papers on Health Education. Brno: MU, MSD, pp. 123-130.

Paulík, K. (2010b). Psychologie lidské odolnosti. Praha: Grada Publishing.

Paulík, K. (2010c). Subjektivní pracovní zátěž a zdraví učitelů a učitelek. In Valihorová, M. \& Kaliská, L. (Eds.). Zdravá škola. Banská Bystrica: UMB PdF, pp. 484-490.

Paulík, K. (2010) Salutogenesis, Perception of Stress and the State of Health of Male and Female Teachers. In Řehulka, E. (Ed.) School and Health. Health Literacy Through Education. Brno: MU, pp. 319-327.

Paulík, K. et al. (2009). Moderátory a mediátory zátěžové odolnosti. Ostrava: FF OU.

Popelková, M., Šišková, A. \& Zažková, M. (2010) Životná spokojnost' a vybrané osbnostné premenné učtel'ov. Psychologie a její kontexty, 1, pp.15-31.

Průcha, J. (2002) Učitel. Současné poznatky o profesi. Praha: Portál.

Sarmány, I. (1992). Škála optimismu-pesimismu. In Prokopčáková, A. \& RUISEL, E. (Eds.) Praktická inteligencia II. Bratislava: UEP SAV, pp. 85-90.

Šolcová, I. \& Kebza, V. (2006). Subjektivní zdraví: Současný stav poznatků a výsledky dvou českých studií. Československá psychologie, 50, 1, pp. 1-15.

Štětovská, I. \& SKALNÍKOVÁ, M. Sociální opora v kontextu proměn role učitele. In Vališová, A., Rymeš, M. \& RIGEL, K. (Eds.) Rozvoj české společnosti v Evropské unii IV. Praha: Matfyspress, pp. 105-119. 
Vašina, B. \& Valošková, M. (1998). Učitel - pracovní zátěž - zdraví. In Řehulka, E. \& Řehulková, O. (Eds). Učitelé a zdraví. Brno: Psychologický ústav AV ČR, pp. 7-24.

\section{Contact:}

prof. PhDr. Karel Paulík, CSc.

Department of Psychology and Applied Social Sciences

Faculty of Arts, University of Ostrava

Reální 5, 70103 Ostrava, Czech Republic

E-mail: paulik@osu.cz

\section{Sociální pedagogika / Social Education}

Is a new peer-reviewed scientific journal that was launched in March 27, 2013. The purpose of the journal is to support information exchange among specialists in social education. In this journal the field of social education is delineated as the study of social aspects of education and development of children, youth and adults. Social education is an interdisciplinary science which collaborates with a number of other disciplines.

The journal publishes two issues per year which are access-free and are accessible at www.soced.cz. The journal publishes theoretical and empirical studies, book reviews and information about scientific events in social education. As concerns the studies, the journal is open to a variety of theoretical conceptions and methodological preferences (quantitative, qualitative, and mixed), provided that they bring new and interesting perspectives. 